\title{
Growth of Escherichia coli and Listeria monocytogenes on radish microgreens washed with sodium hypochlorite during storage
}

\author{
Song-Yi Choi, Hyen Jin Chu, Nagendran Rajalingam, Hyo Bin Chae, \\ Jae-Hyun Yoon, Injun Hwang, Se-Ri Kim* \\ Microbial Safety Team, National Institute of Agricultural Sciences, Rural Development Administration, \\ Wanju 55365, Korea
}

\section{차아염소산나트륨 세척 후 적무 어린잎채소 저장에 따른 Escherichia coli와 Listeria monocytogenes 의 생장}

\author{
최송이·추현진 · Nagendran Rajelingam · 채효빈 · 윤재현 · 황인준 · 김세리* \\ 농촌진흥청 국립농업과학원 농산물안전성부 유해생물팀
}

\begin{abstract}
This study aimed to establish appropriate conditions for the washing and storage of radish microgreens by evaluating the effect of a sodium hypochlorite (NaOCl) wash on the growth of Escherichia coli and Listeria monocytogenes. Sodium hypochlorite $(50,100,150$ and $200 \mathrm{mg} / \mathrm{L})$ was added to wash water and radish microgreens were treated for $5,10,15,20,25$ and $30 \mathrm{~min}$. Treatment with $\mathrm{NaOCl}(150 \mathrm{mg} / \mathrm{L}, 5 \mathrm{~min})$ significantly reduced $(2.3 \mathrm{log} \mathrm{CFU} / \mathrm{g})$ the populations of both bacteria $(\mathbf{p}<\mathbf{0 . 0 5})$. After washing, the levels of bacteria in $\mathrm{NaOCl}$ treated radish microgreens was evaluated during storage at $4^{\circ} \mathrm{C}, 10^{\circ} \mathrm{C}, 15^{\circ} \mathrm{C}$ and $20^{\circ} \mathrm{C}$ for 3 days. The growths of $E$. coli and $L$. monocytogenes increased rapidly at temperatures over $15^{\circ} \mathrm{C}$ and $10^{\circ} \mathrm{C}$ respectively, from day 1 . We believed that $\mathrm{NaOCl}$ treatmentinduced injuries may have caused the release of exudate on microgreen surfaces, which could have facilitated the growth of the pathogens at temperatures $>10^{\circ} \mathrm{C}$. To validate this hypothesis, we inoculated microgreen extract with the pathogens and incubated it under the above mentioned conditions. The growth of pathogens in the microgreens extracts corresponded to that observed after $\mathrm{NaOCl}$ treatment. The results of this study suggest that $\mathrm{NaOCl}$ treatment $(150 \mathrm{mg} / \mathrm{L}, 5 \mathrm{~min})$ and subsequent storage at temperatures $<5^{\circ} \mathrm{C}$ can effectively reduce the growth and survival of $E$. coli and $L$. monocytogenes on radish microgreesns.
\end{abstract}

Key words : Escherichia coli, Listeria monocytogenes, radish microgreens, fresh produce, food safety

서 론

신선편의 식품과 신선편이 농산물은 조리시간을 단축하고 음식물쓰레기 배출을 줄일 수 있어 가정과 급식 및 외식업체 에서의 선호도가 지속적으로 증가하고 있으며, 이러한 이유 로 시장 규모가 점점 확대되고 있다(Kim 등, 2019b). 신선편
의 식품은 ‘농 · 임산물을 세척, 박피, 절단 등의 공정을 거치 거나, 이에 식품 또는 식품첨가물을 가한 것으로, 그대로 섭취할 수 있는 샐러드, 새싹채소 등의 식품'을 말한다(MFDA, 2020b). 신선편이 농산물은 ‘신선한 상태로 다듬거나 절단, 세척 과정 을 거친 과일, 채소, 나물, 버섯류로 위생적으로 포장되어 편 리하게 이용할 수 있는 농산물'이다(MFDA, 2020b). 최근에

*Corresponding author. E-mail : seri81@korea.kr, Phone : +82-10-7665-5793, Fax :+82-63-238-3840

Received 23 October 2020; Revised 02 December 2020; Accepted 21 December 2020.

Copyright (C) The Korean Society of Food Preservation.

This is an Open Access article distributed under the terms of the Creative Commons Attribution Non-Commercial License (http://creativecommons.org/licenses/by-nc/4.0) which permits unrestricted non-commercial use, distribution, and reproduction in any medium, provided the original work is properly cited. 
는 손질된 야채 등 식재료 및 양념이 동봉되어 소비자가 간편 하게 직접 조리해 섭취할 수 있게 만들어진 밀키트(meal kit) 가 주목을 받으면서 신선편이 농산물의 시장은 2020년에 1 조 원을 돌파할 것으로 예측되고 있다(Kim 등, 2019b). 신선 편이 시장이 이러한 경향에 맞춰 빠르게 성장하면서 농산물 에 의한 식중독 사고가 증가하고 있으며, 이에 따라 소비자들 의 우려가 커지고 있다(Callejón 등, 2015). 2004년부터 2010 년 사이 미국에서 발생한 1,779 건의 식품 매개 식중독 사고 중 가열하지 않은 신선한 농산물에 의한 식중독 사고가 차지 하는 비율은 9.2\%(163)였으나, 2010년부터 2017년 사이에는 $12.7 \%(228 / 1797)$ 로 신선한 농산물에 의한 식중독 사고가 차 지하는 비율이 증가하였다. 2010년부터 2017년 신선한 농산 물을 매개로 발생한 식중독 사고 228건 중 85건은 규모가 큰 집단 식중독이었는데, 이로 인해 4,748명의 환자가 발생하고 55 명이 사망하였다. 이 식중독의 주요 원인균은 병원성 Escherichia coli, Listeria monocytogenes, Salmonella spp. 등 이었으며, 새싹채소, 샐러리, 양상추, 멜론 등에 의해 발생하 였다(Carstens 등, 2019).

우리나라에서 어린잎채소는 신선편의 샐러드나 비빔밥 등 의 원료로 사용되는데, 대부분 열처리 공정 없이 제품화되어 유통되고, 소비자가 구매 후에 가열 과정 없이 바로 섭취하기 때문에 관리를 소홀하게 할 경우 식중독 발생 우려가 있어 전처리 및 유통과정에서 철저한 위생관리가 필요하다(Hong 등, 2000). 신선편이 농산물의 유해미생물을 저감화하기 위한 수단으로 살균제를 활용하는데, 식품용으로 사용할 수 있는 살균제는 식품기준 및 규격에 차아염소산나트륨, 오존수, 이 산화염소수, 차아염소산수 등 7가지가 등록되어 있다(MFDA, 2019a). 이러한 살균소독제를 사용하여 농산물 중 식중독세 균을 제어한 이후 적절한 온도에서 관리가 되지 않을 경우, 오히려 식중독미생물의 증식이 용이해질 수 있다. 특히 어린 잎채소는 조직이 연하여 세척이나 포장 과정 중 세포벽이 파 괴되며 조직연화 등의 물리화학적인 변화가 진행되며 미생물 의 오염 및 증식 가능성이 증가할 수 있다(Huxsoll 등, 1989).

따라서 본 연구에서는 샐러드의 재료로 사용되는 농산물 중 적무 어린잎을 대상으로 농산물 즙액의 영양원을 이용한 식중 독 미생물의 생장 가능성을 분석하고, 세척 후 저장 온도에 따 른 적무 어린잎채소 표면에서 E. coli와 L. monocytogenes의 생장을 측정하여 세척한 농산물의 저장 중 미생물 안전성에 대한 분석을 하고자 하였다.

\section{재료 및 방법}

\section{실험재료 및 균주}

본 연구에 사용된 적무 어린잎은 상토를 담은 육묘판에 파
종하여 유리온실 내에서 자연 광조건으로 5일간 재배하여 5-7 $\mathrm{cm}$ 정도 자란 것을 수확하여 사용하였다. 균주는 시중 유통되 는 적무 어린잎채소에서 분리한(Kim 등, 2019) Escherichia coli 3종과 Listeria monocytogenes 3종을 사용하였으며, 시 험균주를 선택적으로 분리하기 위해 rifampicin 저항성을 유 도하였다. Rifampicin 저항성 유도는 tryptic soy agar(TSA; Oxoid, Basingstoke, Hampshire, England) 상에서 배양한 각 균 주를 취하여 $50 \mu \mathrm{L} / \mathrm{mL}$ 의 rifampicin(R; Biosesang, Sungnam, Korea)이 함유된 Luria-Bertani broth(LB, Oxoid)에 접종하고 $37^{\circ} \mathrm{C}$ 에서 24 시간 진탕 배양하였다. 이후 $50 \mu \mathrm{L} / \mathrm{mL}$ 의 rifampicin이 함유된 Luria-Bertani agar(LA, Oxoid)에 접종 하고, $37^{\circ} \mathrm{C}$ 에서 24 시간 배양하여 rifampicin 저항성 균주을 유도하였다. Rifampicin 저항성 균주는 rifampicin $50 \mu \mathrm{L} / \mathrm{mL}$ 를 첨가한 tryptic soy broth(TSB-R, Oxoid)에 $20 \%$ glycerol 를 첨가하여 $-70^{\circ} \mathrm{C}$ 에서 보관하였다.

\section{적무 어린잎채소 즙액에서 $E$. coli와 L. monocytogenes 의 생장 조사}

E. coli와 L. monocytogenes가 적무 어린잎채소에서 유래 된 영양원을 활용한 성장 특성을 온도별로 조사하였다. 이를 위하여 적무 어린잎채소 착즙액을 제조하였다. 어린잎채소를 마쇄하여 4,000 rpm에서 5 분간 원심분리하여 상등액을 취한 후 상등액을 $0.45 \mu \mathrm{m}$ 필터(Merck Millipore, Ltd., Cork, Ireland)를 이용하여 1차 여과하고, $0.22 \mu \mathrm{m}$ 필터(Merck Millipore, Ltd.)로 2차 여과하였다. 착즙액 $1 \mathrm{~mL}$ 를 $99 \mathrm{~mL}$ $\mathrm{PBS}$ 로 희석하여 $1 \%$ 착즙배지를 제조하였으며, 대조구로는 $\mathrm{TSB}$ 과 $\mathrm{PBS}$ 를 사용하였다. 앞서 배지성분을 제거한 E. coli 와 L. monocytogenes 현탁액을 희석하여 $3 \log \mathrm{CFU} / \mathrm{mL}$ 수 준이 되도록 $1 \%$ 적무 어린잎채소 추출액, $\mathrm{TSB}, \mathrm{PBS}$ 에 각각 접종하고, $4,10,15,20^{\circ} \mathrm{C}$ 에서 배양하였다. 각각의 배지에 접 종한 E. coli와 L. monocytogenes의 시간과 온도에 따른 균수 를 측정하기 위해 $E . c o l i$ 는 $4,10^{\circ} \mathrm{C}$ 에서는 24 시간 간격으로, $15^{\circ} \mathrm{C}$ 에서는 12 시간, $20^{\circ} \mathrm{C}$ 에서는 6 시간 간격으로 균수를 측정 하였으며, L. monocytogenes는 $4^{\circ} \mathrm{C}$ 에서는 24 시간, $10^{\circ} \mathrm{C}$ 에서 는 12 시간, $15,20^{\circ} \mathrm{C}$ 에서는 6 시간 간격으로 균수를 측정하였 다. 균수 확인은 접종액을 $1 \mathrm{~mL}$ 씩 취해 $0.1 \%$ peptone water 로 단계희석하고, $100 \mu \mathrm{L}$ 를 취하여 E. coli는 TSA-R에, $L$. monocytogenes는 Yeast extract(YE, Oxoid)가 첨가된 TSA-YE-R에 도말한 후 $37^{\circ} \mathrm{C}$ 에서 24 시간 배양하였다.

\section{차아염소산나트륨 이용 적무 어린잎채소의 살균 소독 조건 설정}

적무 어린잎의 차아염소산나트륨을 이용하여 최적의 살균 소독 조건을 확립하기 위하여 E. coli와 L. monocytogenes를 
어린잎에 접종하였고, 차아염소산나트륨에 노출시켰다. 먼 저 대상균주를 각각 상온에서 해동한 후 $10 \mu \mathrm{L}$ 를 취하여 10 $\mathrm{mL}$ 의 TSB-R에 넣고 $37^{\circ} \mathrm{C}$ 에서 18 시간 동안 배양하였다. 배 양한 세균 현탁액은 배지성분을 제거하기 위해 $4,500 \times g$ 에 서 15 분간 원심분리한 후 phosphate buffered saline(PBS; Difco Laboratories, Detroit, MI, USA)으로 현탁하였다. 위 과정을 3회 반복한 후 각각의 균주 $1 \mathrm{~mL}$ 를 혼합하여 농도가 $6 \log \mathrm{CFU} / \mathrm{mL}$ 가 되도록 희석하였다. 희석한 혼합배양액 10 $\mathrm{mL}$ 를 어린잎 $100 \mathrm{~g}$ 에 spotting한 후 골고루 섞어 주어 무균 대 내에서 2 시간 동안 건조하였다. 균주가 접종된 어린잎채 소 $10 \mathrm{~g}$ 을 차아염소산나트륨수(Yuhanrox, Seoul, Korea) 50, $100,150,200 \mathrm{mg} / \mathrm{L}$ 에 $5,10,15,20,25,30$ 분간 침지하였다. 미생물 저감효과를 확인하기 위하여 어린잎채소 $10 \mathrm{~g}$ 에 소독 제의 효과를 중화시키기 위한 D/E neutralizing broth(Difco Laboratories) $90 \mathrm{~mL}$ 를 넣고 stomacher로 2분간 처리하였다. 그 중 $1 \mathrm{~mL}$ 를 취하여 단계희석하고 희석액 $100 \mu \mathrm{L}$ 를 $E$. coli는 TSA-R 배지에, L. monocytogenes는 Yeast extract (YE)가 첨가된 TSA-YE-R에 도말하고, $37^{\circ} \mathrm{C}$ 에서 24시간 배 양하였다.

\section{세척 적무 어린잎채소의 저장온도에 따른 $E$. col/와 $L$. monocytogenes의 생장특성 조사}

세척 후 저장 중 어린잎채소의 E. coli와 L. monocytogenes 의 생장특성을 조사하기 위해 E. coli와 L. monocytogenes를 앞서 차아염소산나트륨 세척소독 조건 확립실험에 언급한 바 와 같이 접종하였다. 세척하지 않은 어린잎채소, 멸균수로만 3 회 세척한 어린잎채소, $150 \mathrm{mg} / \mathrm{L}$ 의 차아염소산나트륨수로 5 분간 세척하고, 멸균수로 2 회 헹굼 처리한 어린잎채소를 $\mathrm{PE}$ 재질의 비닐포장지에 $10 \mathrm{~g}$ 씩 넣고 밀봉하여 $4,10,15,20^{\circ} \mathrm{C}$ 에 저장하였다. 세척 및 저장에 따른 미생물 생육을 확인하기 위하여 어린잎채소 $10 \mathrm{~g}$ 에 $\mathrm{D} / \mathrm{E}$ broth $90 \mathrm{~mL}$ 를 넣고 stomacher(Interscience, Normandie, France)로 2분간 균질화하 였다. 그 중 $1 \mathrm{~mL}$ 를 취하여 $0.1 \%$ peptone water(Difco Laboratories)로 단계희석하고, $100 \mu \mathrm{L}$ 를 취하여 E. coli는 TSA-R배지에, L. monocytogenes는 TSA- YE-R에 도말하고 $37^{\circ} \mathrm{C}$ 에서 24 시간 배양하였다.

\section{통계처리}

모든 실험은 3 반복으로 수행되었으며, 관찰된 실험결과의 처리간 효과는 SAS 통계 프로그램(version 9.1, SAS Institute, $\mathrm{NC}, \mathrm{USA})$ 의 분산분석(ANOVA procedure)을 이용하여 분석하 였다. $p<0.05$ 수준에서 처리효과가 유의적인 경우에는 Tukey's HSD test를 이용하여 평균간 다중비교를 하였다.

\section{결과 및 고찰}

\section{적무 어린잎채소 즙액에서 저장온도에 따른 $E$. col와 $L$. monocytogenes의 생장특성}

E. coli와 L. monocytogenes가 적무 어린잎채소에서 유래 된 영양원을 활용하여 성장하는 특성을 분석하기 위해 적무 어린잎채소 $1 \%$ 착즙액에 각각 접종 후 $4,10,15,20^{\circ} \mathrm{C}$ 에 7 일 간 저장하며 균수를 측정하였다. 풍부한 영양원이 제공되는 양성 대조군으로 $\mathrm{TSB}$ 를 사용하였고, 영양원이 없는 음성 대 조군으로 $\mathrm{PBS}$ 를 사용하였다. E. coli를 각각의 배지에 접종 하여 $4,10^{\circ} \mathrm{C}$ 에 7 일간 저장했을 때 $1 \%$ 착즙액과 영양이 풍부 한 TSB에서 모두 성장하지 않았다(Fig. 1). $15^{\circ} \mathrm{C}$ 에서 배양 시 초기 접종 농도는 $2.6 \log \mathrm{CFU} / \mathrm{mL}$ 였으며, $1 \%$ 착즙액에서는 72시간 후에 $6.3 \log \mathrm{CFU} / \mathrm{mL}$ 로 증식하였고, TSB에서도 6.3 $\log \mathrm{CFU} / \mathrm{mL}$ 로 같은 수준으로 증식하였다. 그러나 최대 증식 농도에서 차이를 보였는데, $1 \%$ 착즙액에서는 최대 $7.2 \mathrm{log}$ $\mathrm{CFU} / \mathrm{mL}$ 까지 증식하였으나, TSB에서는 $8.8 \log \mathrm{CFU} / \mathrm{mL}$ 까 지 증식하였다. $20^{\circ} \mathrm{C}$ 에서 배양한 $E$. coli의 경우 배양 6 시간 후부터 증식하기 시작하여 $1 \%$ 착즙액에서는 배양 30 시간 후 $7.4 \log \mathrm{CFU} / \mathrm{mL}$ 로 빠르게 성장하였고, TSB에서는 6시간 이 후 증식하기 시작하여 배양 30시간 후 $8.1 \log \mathrm{CFU} / \mathrm{mL}$ 로 증 식하였다. 실험결과, E. coli는 $1 \%$ 착즙액에서 생육 시 최대 증식 균수가 영양성분이 풍부한 $\mathrm{TSB}$ 보다 $15^{\circ} \mathrm{C}$ 에서는 1.6 $\log \mathrm{CFU} / \mathrm{mL}$ 낮게 성장하였고, $20^{\circ} \mathrm{C}$ 에서는 $0.7 \log \mathrm{CFU} / \mathrm{mL}$ 낮게 측정되었다. 영양이 풍부한 $\mathrm{TSB}$ 에 비해 $1 \%$ 착즙액에 서 최대 증식 농도는 낮게 나타났으나, 최대 증식 농도에 도 달 하는 시간은 영양배지와 유사하여 E. coli가 적무 어린잎 착즙액의 영양원을 활용하여 활발하게 증식한 것을 확인할 수 있었다. L. monocytogenes를 E. coli와 같은 방법으로 배지에 접종하여 생육 특성을 측정 결과, $\mathrm{TSB}$ 와 $1 \%$ 착즙액에서 모 두 $4^{\circ} \mathrm{C}$ 에서는 7 일간 성장하지 않았으나, $10^{\circ} \mathrm{C}$ 에서는 12 시간이 지난 이후부터 성장을 하기 시작하였다(Fig. 2). 초기 접종농도 는 $3.1 \log \mathrm{CFU} / \mathrm{mL}$ 였고, $1 \%$ 착즙액을 $10^{\circ} \mathrm{C}$ 에서 144 시간 배 양 시 $7.6 \log \mathrm{CFU} / \mathrm{mL}$ 까지 증식하였으며, TSB에서는 $9.4 \mathrm{log}$ $\mathrm{CFU} / \mathrm{mL}$ 까지 증식하였다. $15^{\circ} \mathrm{C}$ 에서 배양한 L. monocytogenes 는 $1 \%$ 착즙액과 $\mathrm{TSB}$ 에서 모두 6시간 이후 증식하기 시작하 여 $1 \%$ 착즙액에서는 배양 48 시간째 최대 농도인 $7.8 \mathrm{log}$ $\mathrm{CFU} / \mathrm{mL}$ 로 증식하였고, TSB에서는 60시간째 $9.3 \log \mathrm{CFU} / \mathrm{mL}$ 로 증식하였다. $20^{\circ} \mathrm{C}$ 에서 배양한 경우, 3 시간 이후부터 빠르 게 증식하여 $1 \%$ 착즙액에서는 24 시간 째 $7.9 \log \mathrm{CFU} / \mathrm{mL}$, $\mathrm{TSB}$ 에는 30 시간째에 각각 $9.4 \log \mathrm{CFU} / \mathrm{mL}$ 로 최대 농도에 도달하였다. 영양분이 $\mathrm{TSB}$ 에 비해 상대적으로 적은 $1 \%$ 착 즙액에서는 최대 증식 농도가 $1.5-1.8 \log \mathrm{CFU} / \mathrm{mL}$ 낮게 측 정되었으나, 균수가 증가하는 패턴은 유사하게 나타났다. 이 
(A)

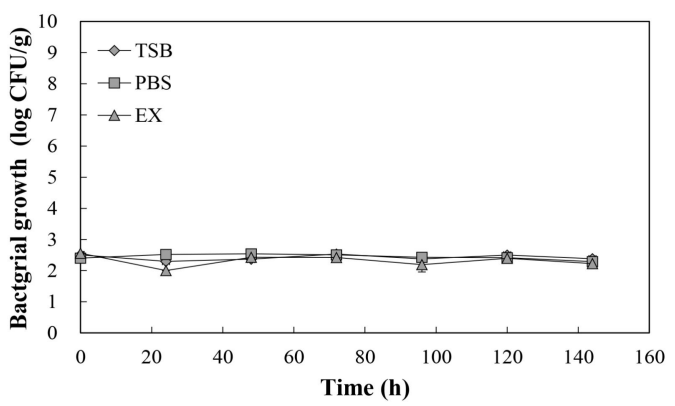

(C)

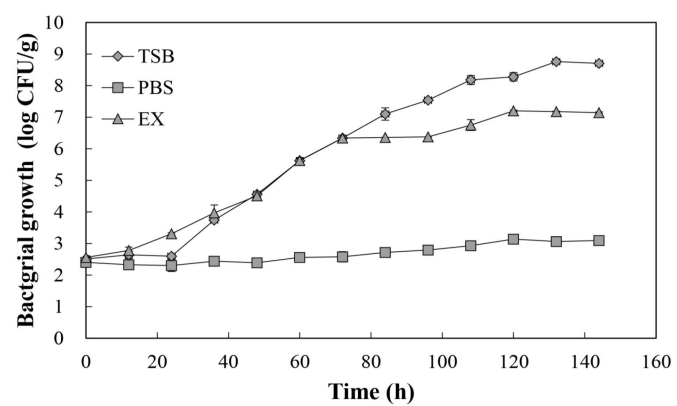

(B)

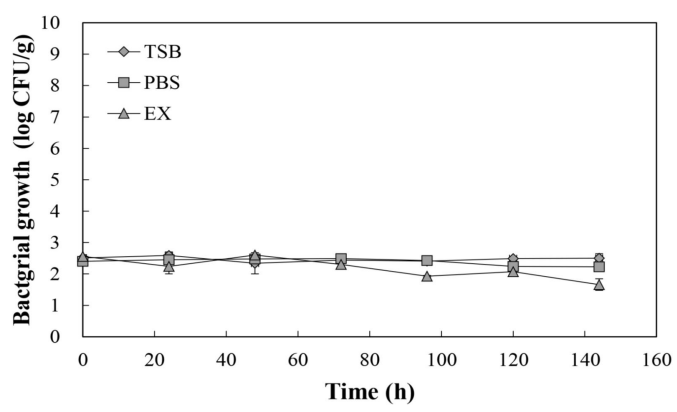

(D)

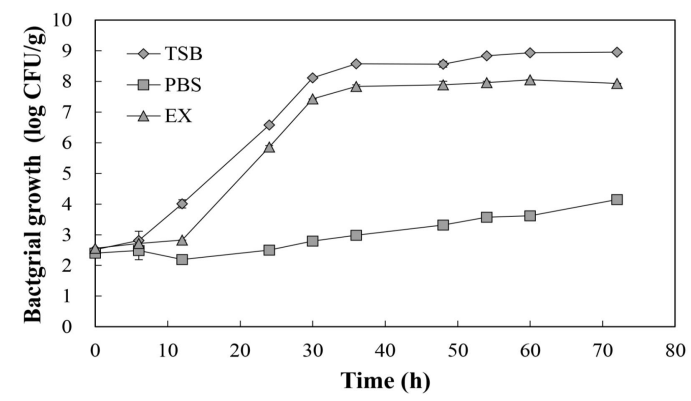

Fig. 1. Behavior of Escherichia coli inoculated in extract of red radish leaves during incubation at (A) $4^{\circ} \mathrm{C},(\mathrm{B}) 10^{\circ} \mathrm{C},(\mathrm{C}) 15^{\circ} \mathrm{C}$, and (D) $20^{\circ} \mathrm{C}$. Values are the average of samples from each of four experiments, error bars represent standard deviations.

(A)

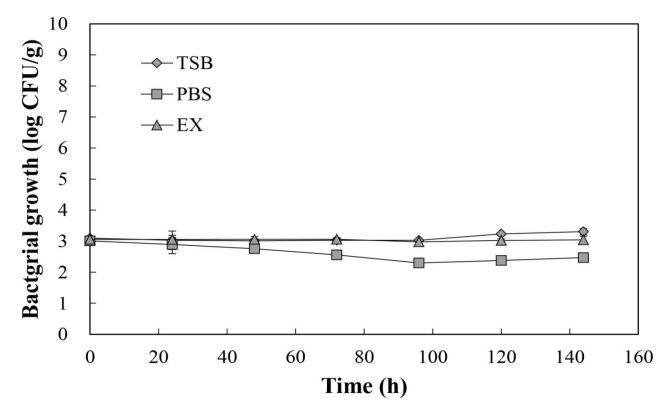

(C)

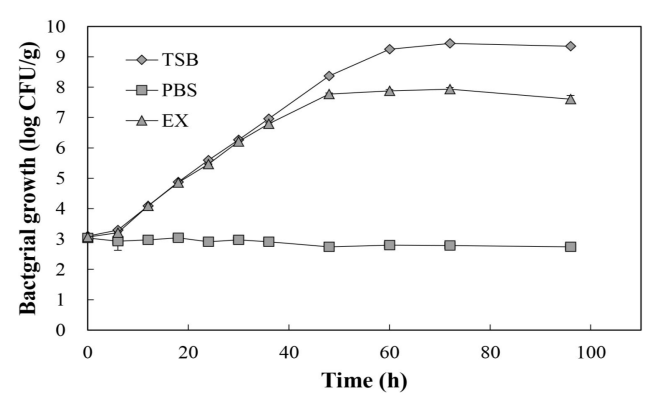

(B)

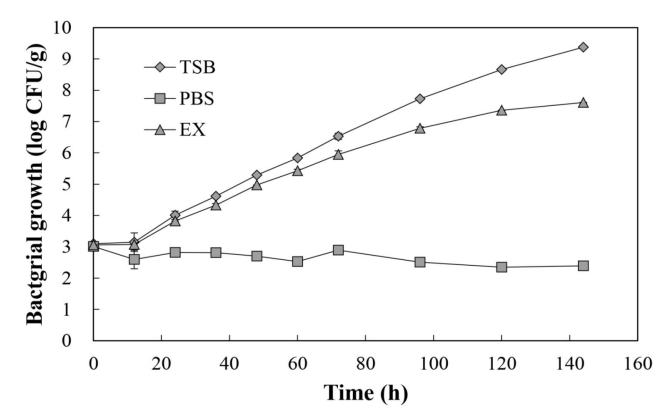

(D)

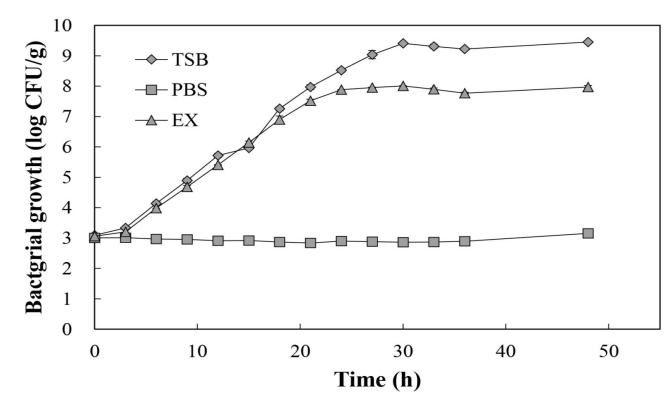

Fig. 2. Behavior of Listeria monocytogenens inoculated in extract of red radish leaves during incubation at $(\mathrm{A}) 4^{\circ} \mathrm{C},(\mathrm{B}) 10^{\circ} \mathrm{C},(\mathrm{C}) 15^{\circ} \mathrm{C}$, and (D) $20^{\circ} \mathrm{C}$.

Values are the average of samples from each of four experiments, error bars represent standard deviations. 
는 $\mathrm{Kim}$ 등(2011)이 상추잎 즙액에서 E. coli $\mathrm{O} 157: \mathrm{H} 7$ 의 생 장 가능성을 측정한 연구 결과와 유사하였으며, 본 실험을 통 해 적무 어린잎채소에서 착즙된 영양원이 미생물이 증식하기 에 충분한 환경을 제공하는 것으로 나타났다.

\section{차아염소산나트륨을 이용한 적무 어린잎채소의 살균 소독 조건 설정}

적무 어린잎채소 세척 후 저장 효과를 분석하기 위하여 우 선 차아염소산나트륨 최적 세척 조건을 선정하였다. E. coli 와 L. monocytogenes 를 어린잎채소에 접종하여 50,100 , $150,200 \mathrm{mg} / \mathrm{L}$ 에서 5 분 간격으로 30 분까지 침지한 후 살균 효과를 조사하였다. $50,100 \mathrm{mg} / \mathrm{L}$ 의 농도로 5 분간 세척 시 E. coli는 1.1, $1.5 \log \mathrm{CFU} / \mathrm{g}$, L. monocytogenes는 1.2, 1.5 $\log \mathrm{CFU} / \mathrm{g}$ 정도 감소하였고(Fig. 3), $50 \mathrm{mg} / \mathrm{L}$ 와 $100 \mathrm{mg} / \mathrm{L}$ 간 의 유의적인 차이는 없었다( $>00.05)$. 그러나 $150 \mathrm{mg} / \mathrm{L}$ 로 5 분 간 세척했을 경우 E. coli와 L. monocytogenes 모두 $2.3 \mathrm{log}$ $\mathrm{CFU} / \mathrm{g}$ 의 감소효과가 있었다. E. coli를 접종 후 $150 \mathrm{mg} / \mathrm{L}$ 와 $200 \mathrm{mg} / \mathrm{L}$ 의 농도로 세척한 처리구 간에는 유의적인 차이가 없었으며, 5 분 이상 처리하여도 더 이상 저감 효과를 나타내 지 않았다(p>0.05). L. monocytogenes의 경우에도 $150 \mathrm{mg} / \mathrm{L}$ 에서 5 분간 처리 시 $2.3 \log \mathrm{CUF} / \mathrm{g}$ 감소하였고, $150 \mathrm{mg} / \mathrm{L}$ 와 $200 \mathrm{mg} / \mathrm{L}$ 처리구 간의 유의적인 차이는 없었다. 그러나 $E$. coli와는 다르게 $100 \mathrm{mg} / \mathrm{L}$ 로 15 분간 침지했을 경우 150,200 $\mathrm{mg} / \mathrm{L}$ 처리구와 유사한 저감 효과를 나타내었다. 신선편이 농 산물의 세척 공정은 토양이나 벌레 등의 이물을 제거할 뿐만 아니라, 초기 미생물 생균수를 낮춰 제품의 안전과 품질을 관리하기 위한 중요한 단계이다(Kim, 2005). 그러나 농산물

(A)

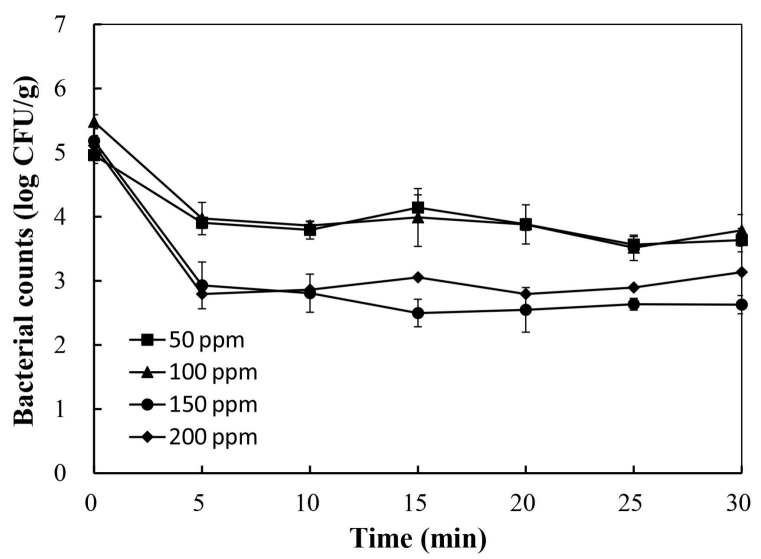

을 물로만 세척할 경우, 미생물이 0.2-0.8 $\log \mathrm{CFU} / \mathrm{g}$ 정도 감소된다는 Kwon 등(2006)과 Park 등(2012)의 연구 결과에 따르면 물세척의 감소효과는 크지 않기 때문에 신선농산물 의 미생물 안전관리를 위해 보편적으로 살균소독제를 사용 하고 있다. 학교급식 위생관리 지침서(Ministry of Education, 2016)에서는 생으로 먹는 채소 및 과일류는 차아염소산나트 륨으로 세척 시 유효염소농도 $100 \mathrm{mg} / \mathrm{L}$ 로 5 분간 침지 후 먹 는 물로 씻어 관리하도록 제시하고 있다. 그러나 최 등(2008) 의 연구결과에서 양상추를 차아염소산나트륨 $100 \mathrm{mg} / \mathrm{L}$ 로 5 분간 처리했을 때 병원성 미생물의 감소 효과는 0.8-0.9 log $\mathrm{CFU} / \mathrm{g}$ 였고, Lee 등(2011)이 메밀 새싹에 동일한 농도와 시 간으로 처리한 결과, 미생물이 $1 \log \mathrm{CFU} / \mathrm{g}$ 정도 감소하여 미생물 제어 효과가 미미한 것으로 나타났다. 차아염소산나 트륨은 수용액 상에서 강력한 산화력을 가지는 차아염소산 (hypochlorous acid, $\mathrm{HOCl}$ )을 형성하는데, 이는 미생물의 세 포벽을 통과하여 DNA를 손상시키거나, 세포의 대사를 방해 하고 효소를 불활성화시켜 살균작용을 일으키는 것으로 알려 져 있다 (Estrela 등, 2002; Fukuzaki, 2006; Kim, 2001). 염소 계 소독제의 경우, in vitro 상에서는 3-5 $\log \mathrm{CFU} / \mathrm{g}$ 의 저감효 과를 보이나(Elano 등, 2010), 식품에 적용 시 $\mathrm{pH}$ 와 유기물 등에 의해 세척 효과가 감소된다(Kim등, 2009). Yoon 등 (2017)의 연구에서는 부추에 차아염소산나트륨을 $100 \mathrm{mg} / \mathrm{L}$ 처리했을 때 E. coli가 $2.4 \log \mathrm{CFU} / \mathrm{g}$ 의 감소하는 효과가 있 었고, Park 등(2012) 등의 연구에서는 배추에 $3 \log \mathrm{CFU} / \mathrm{g}$ 이 상 감소 효과가 있었으나, 본 연구에서는 $150 \mathrm{mg} / \mathrm{L}$ 의 농도에 서 유사한 효과가 나타난 것은 농산물의 특성에 따라 소독 효과가 상이하게 작용할 수 있기 때문이다. 따라서 적무 어린

(B)

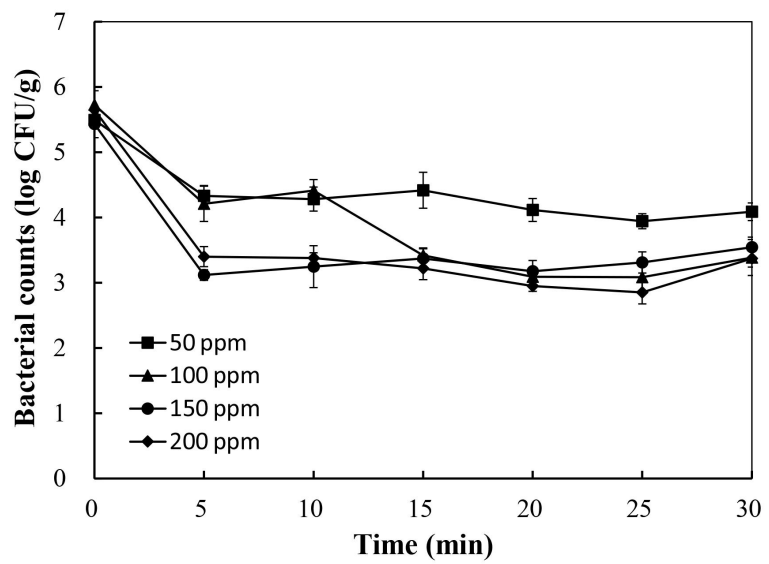

Fig. 3. Effect of sodium hypochlorite treatment $(50-200 \mathrm{mg} / \mathrm{L})$ on the population of (A) E. coli and (B) L. monocytogenes inoculated on baby leaves.

Values represent the mean of triplicate measurements. Bars denote the standard deviation. 
잎을 세척할 때 E. coli와 L. monocytogens에서 $2 \log \mathrm{CFU} / \mathrm{g}$ 이상의 저감효과를 나타내는 조건으로 $150 \mathrm{mg} / \mathrm{L}$ 에서 5 분간 처리하는 것이 효과적일 것으로 판단된다.

\section{세척 후 적무 어린잎채소의 저장온도에 따른 $E . c o /$ 와 L. monocytogenes의 생장 특성}

적무 어린잎채소를 차아염소산나트륨으로 세척 후 저장 온도가 미생물의 균수 변화에 미치는 영향을 분석하기 위해 적무 어린잎채소에 E. coli와 L. monocytogenes를 접종하여 차아염소산나트륨 $150 \mathrm{mg} / \mathrm{L}$ 로 5 분간 세척한 후 온도 별로 저장하였다. 3 일간 24 시간 간격으로 균 수를 측정하였고, 세 척하지 않은 어린잎과 물로만 세척한 어린잎을 대조군으로 하였다. 먼저 E. coli의 경우 각각의 시료를 $4,10^{\circ} \mathrm{C}$ 에 3 일간 저장했을 때 세척 여부에 상관없이 균 수가 증가하지 않았다 (Fig. 4). 그러나 $15^{\circ} \mathrm{C}$ 에 저장했을 경우, 소독제로 세척한 어 린잎에서는 균수가 0.7-1.2 $\log \mathrm{CFU} / \mathrm{g}$ 증가하였고, 물로 세
척한 어린잎채소는 0.2-0.9 $\log \mathrm{CUF} / \mathrm{g}$, 세척하지 않은 어린 잎채소에서는 0.1-0.6 $\log \mathrm{CFU} / \mathrm{g}$ 증가하는 경향이 나타났다. 세척하지 않은 시료보다 세척한 처리구에서 저장 후 균수가 더 높게 측정되었으며, 세척한 처리구 중에서도 물로 세척한 것보다 차아염소산나트륨으로 세척한 처리구에서 균수가 더 높게 측정되었다. 물로만 세척한 것보다 소독제로 세척한 어 린잎에서 E. coli가 더 빠르게 증식하긴 하였으나 저장 3 일 후 미생물의 균수는 소독제로 세척한 어린잎에서의 균수(4.3 $\log \mathrm{CFU} / \mathrm{g})$ 가 물로만 세척한 것(5.1 $\log \mathrm{CUF} / \mathrm{g})$ 보다는 낮았 다. $20^{\circ} \mathrm{C}$ 에서는 저장 1 일째부터 세척한 처리구의 미생물 수 가 대조구의 초기 접종 농도(5.4 $\log \mathrm{CFU} / \mathrm{g})$ 와 유사하게 증식 하였고, 물로만 세척한 실험구와 소독제로 세척한 실험구 간 에 유의적인 차이가 없었다( $\mathrm{p}>0.05)$. 결과를 종합해 보면 4 , $10^{\circ} \mathrm{C}$ 에서는 3 일간 저장 시 소독제로 인한 $E . c o l i$ 의 살균효과 가 유지되었으며, $15^{\circ} \mathrm{C}$ 에서는 소독제로 세척한 것이 $1 \log$ $\mathrm{CFU} / \mathrm{g}$ 이 증가하였고 $20^{\circ} \mathrm{C}$ 에서는 $2 \log \mathrm{CFU} / \mathrm{g}$ 이 증가하였다.
(A)

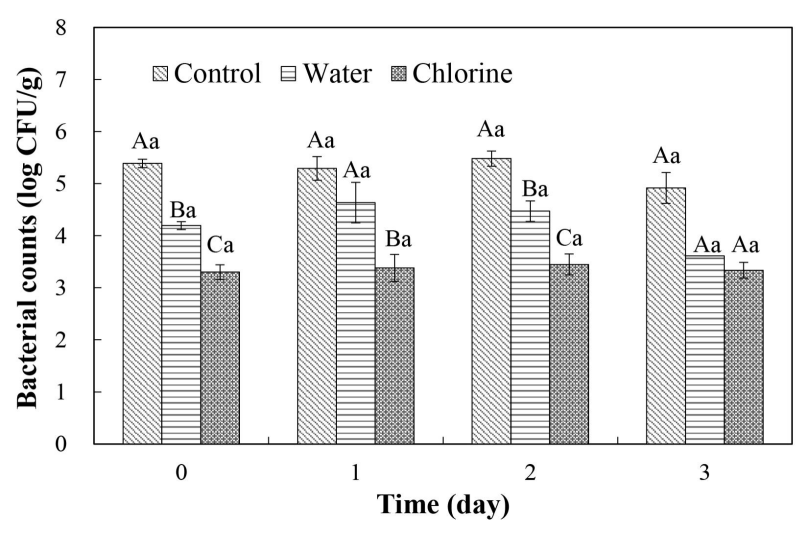

(C)

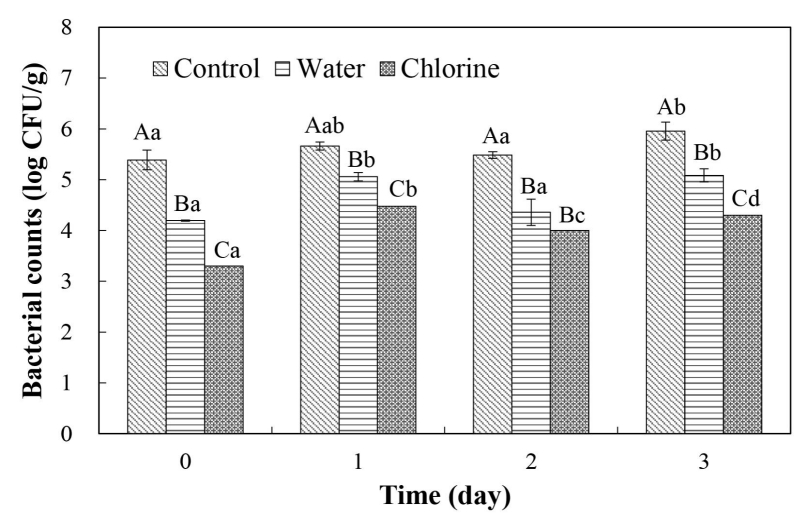

(B)

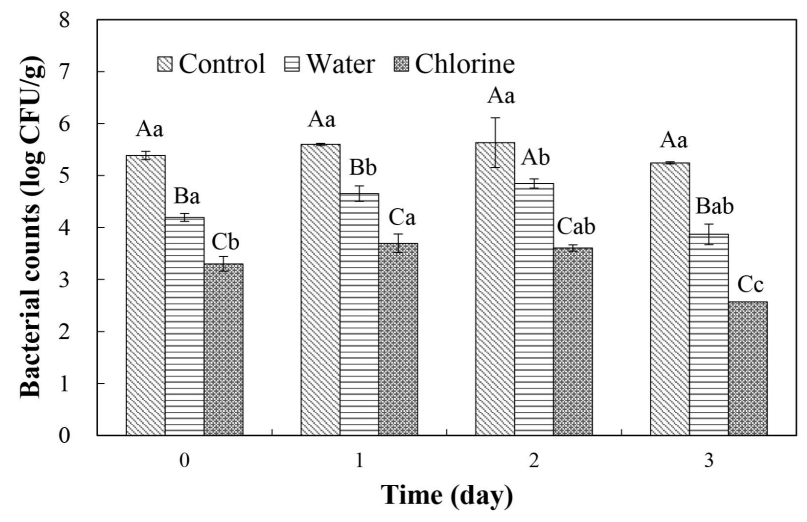

(D)

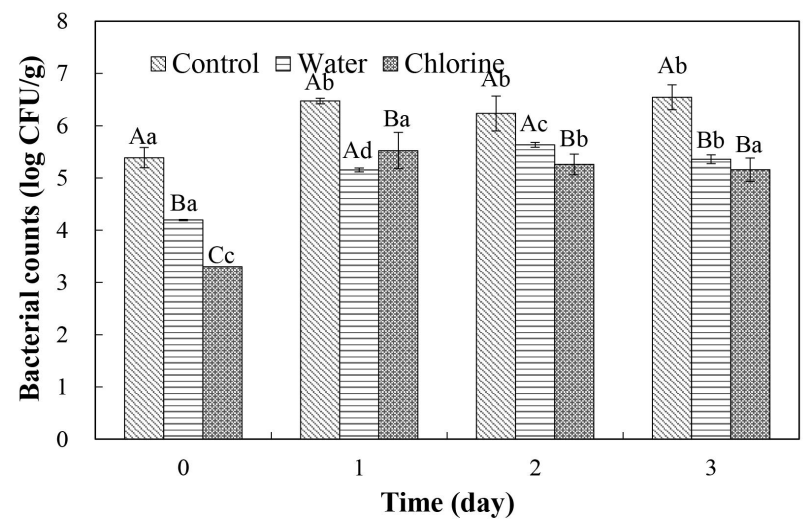

Fig. 4. Population of Escherichia coli in red radish leaves treated with sodium hypochlorite $150 \mathrm{mg} / \mathrm{L}$ for 5 min during storage at (A) $4^{\circ} \mathrm{C}$ (B) $10^{\circ} \mathrm{C}$ (C) $15^{\circ} \mathrm{C}$, and (D) $20^{\circ} \mathrm{C}$.

Values represent the means of triplicate measurements. Bars denote the standard deviation; different capital letters indicate significant difference among washing methods; different small letters indicate significant difference according to the storage period. 
또한 $15^{\circ} \mathrm{C}$ 와 $20^{\circ} \mathrm{C}$ 에서 모두 물로만 세척한 것보다 소독제로 세척한 것에서 미생물의 증식속도가 빠른 것으로 나타났다.

L. monocytogenes는 $-2^{\circ} \mathrm{C}$ 의 저온에서도 생육이 가능한 병원성 미생물로 알려져 있다. 본 실험에서 어린잎에 $L$. monocytogenes 를 접종하여 세척 후 3 일간 저장했을 때 $4^{\circ} \mathrm{C}$ 에서는 모든 실험구에서 균수가 증가하지 않았다(Fig. 5). 그 러나 E. coli와는 다르게 $10^{\circ} \mathrm{C}$ 에 저장했을 경우 저장 1 일째부 터 모든 실험구에서 증식하기 시작하였으며, 차아염소산나트 륨으로 세척한 어린잎채소에서는 저장 3일 동안 1.2-2.0 log $\mathrm{CFU} / \mathrm{g}$ 증식하였다. 물로만 세척한 실험구에서는 1.1-1.4 log $\mathrm{CFU} / \mathrm{g}$ 증식하였고, 세척하지 않은 실험구에서는 0.6-0.8 log $\mathrm{CFU} / \mathrm{g}$ 증식하여 차아염소산나트륨으로 세척한 농산물에서 다른 실험구에 비해 빠르게 증식하는 것으로 나타났다. $10^{\circ} \mathrm{C}$ 에서 저장 2 일째에는 소독제로 세척한 어린잎에서의 균수가 대조구의 초기 접종 농도인 $4.7 \log \mathrm{CFU} / \mathrm{g}$ 과 유사한 농도로 증식하였으며, 저장 3 일째에는 처리구 간의 유의적 차이 없이

(A)

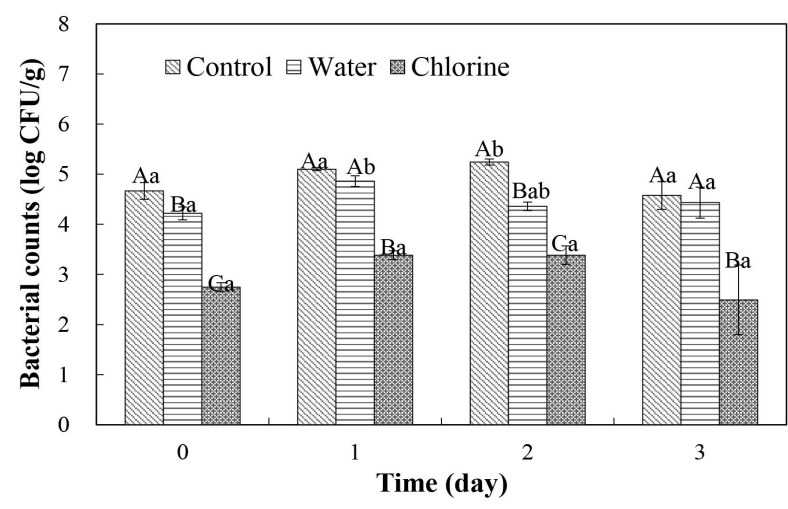

(C)

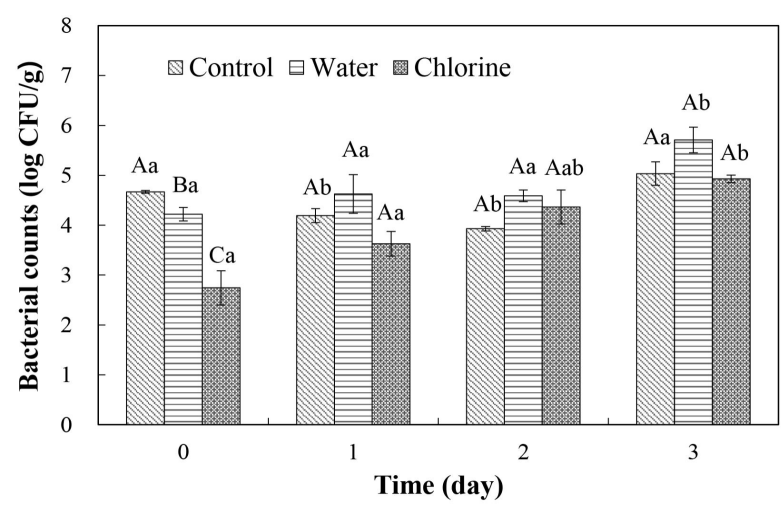

4.7-5.5 $\log \mathrm{CFU} / \mathrm{g}$ 수준으로 증식하였다. $15,20^{\circ} \mathrm{C}$ 에 저장했 을 때는 1 일째부터 모든 실험구 간 유의적인 차이가 없어 세 척으로 인한 미생물 저감효과가 사라지는 것으로 나타났다. 세척하지 않은 적무 어린잎채소 표면에서는 $4-15^{\circ} \mathrm{C}$ 에 3 일간 저장하여도 미생물이 $0.8 \log \mathrm{CFU} / \mathrm{g}$ 이상 증식하지 않았으 나, 차아염소산나트륨으로 세척한 농산물에서는 E. coli의 경 우 $15^{\circ} \mathrm{C}$ 에서 저장 3 일 후 $1 \log \mathrm{CFU} / \mathrm{g}$ 이상 증식하였고, $L$. monocytogenes 의 경우 $10^{\circ} \mathrm{C}$ 에서 저장 3 일 후 $2.0 \log \mathrm{CFU} / \mathrm{g}$ 증식하였다. 식중독 미생물은 농산물의 표면에서는 증식하기 어려우나(Harapas 등, 2010), 채소의 어린잎은 조직이 연하기 때문에 세척 과정에서 손상을 입을 수 있으며, 농산물의 손상 된 부분에서 영양분이 유출되어(Brandl, 2008) 미생물이 활 용할 수 있게 된다. 이는 적무 어린잎채소 즙액 $1 \%$ 에서 미생 물의 온도별 증식패턴과 세척한 농산물에서의 증식패턴이 유 사한 경향을 나타내어 세척 과정에서 손상된 조직에서 유출 된 영양성분을 활용하여 증식한 것으로 판단할 수 있다.
(B)

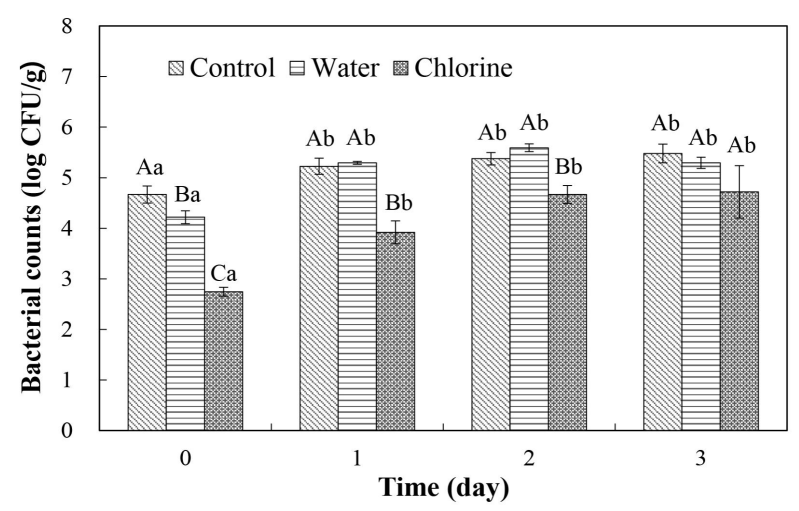

(D)

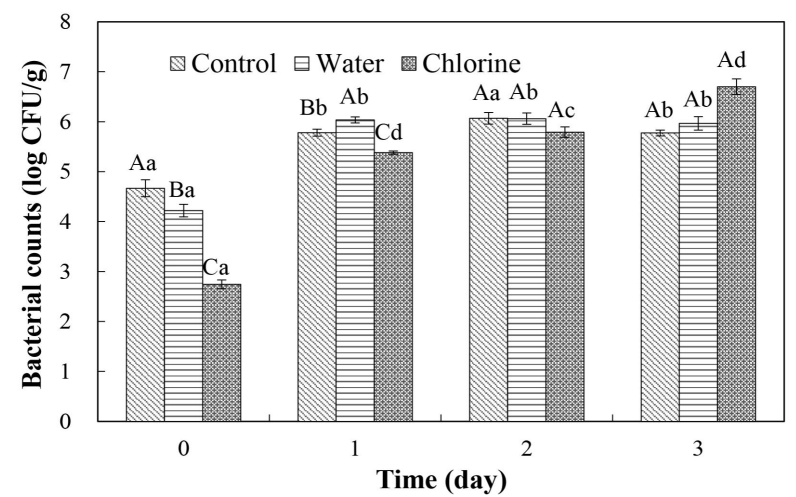

Fig. 5. Population of Listeria monocytogenes in red radish leaves treated with sodium hypochlorite $150 \mathrm{mg} / \mathrm{L}$ for $5 \mathrm{~min}$ during storage at (A) $4^{\circ} \mathrm{C}$, (B) $10^{\circ} \mathrm{C}$, (C) $15^{\circ} \mathrm{C}$, and (D) $20^{\circ} \mathrm{C}$.

Values represent the means of triplicate measurements. Bars denote the standard deviation; different capital letters indicate significant difference among washing methods; different small letters indicate significant difference according to the storage period. 
따라서 소독제를 사용하여 농산물을 세척 한 이후에 온도 가 $4^{\circ} \mathrm{C}$ 이하로 관리되지 않을 경우, 오히려 미생물의 오염도 가 증가할 수 있으므로 세척한 농산물에서 미생물 안전성을 확보하기 위해서는 저장 및 유통온도 관리가 철저하게 이루 어져야 할 것으로 사료된다.

\section{요 약}

본 연구는 적무 어린잎채소의 미생물학적 안전성을 확보 하고자 적무 어린잎채소의 세척 소독 조건을 확립하고, 세척 소독 후 저장에 따른 식중독세균의 생장 특성을 조사하였다. 이를 위하여 E. coli와 L. monocytogenes를 접종하고, 차아염 소산나트륨수 $50,100,150,200 \mathrm{mg} / \mathrm{L}$ 에 $5,10,15,20,25$, 30 분간 처리하였다. 또한, 적무 어린잎채소를 차아염소산나 트륨 $150 \mathrm{mg} / \mathrm{L}$ 로 5 분간 처리 후 $4,10,15,20^{\circ} \mathrm{C}$ 에서 3 일간 저장하면서 식중독세균의 균수 변화를 조사하였다. 식중독 세균이 적무 어린잎에서 유래된 영양원을 활용하여 성장하 는 특성을 분석하기 위해 적무 어린잎 $1 \%$ 착즙액에서 생장 도 조사하였다. 그 결과, 적무 어린잎채소를 차아염소산나트 륨수 $150 \mathrm{mg} / \mathrm{L}$ 로 5 분간 세척하였을 때 $E$. coli와 $L$. monocytogenes가 모두 $2.3 \log \mathrm{CFU} / \mathrm{g}$ 감소하였다 $(\mathrm{p} \leq 0.05)$. 또한 차아염소산나트륨 $150 \mathrm{mg} / \mathrm{L}$ 를 5 분간 처리하고 저장하 였을 때 3 일째에 $E$. coli는 $15^{\circ} \mathrm{C}$ 에서 $1 \log$ cycle, $20^{\circ} \mathrm{C}$ 에서는 $2 \log$ cycle 증가하였다(p $\leq 0.05)$. L. monocytogenes의 경우 는 $10^{\circ} \mathrm{C}$ 이상의 온도에서 1 일째부터 증식하여 저장 3 일째에 는 소독제 처리 여부에 관계없이 모두 $2 \log$ cycle 이상 증 식하였다. $1 \%$ 적무 어린잎채소 추출액에서 E. coli와 $L$. monocytogenes를 접종하여 $4,10,15,20^{\circ} \mathrm{C}$ 에서 배양한 결과, 적무 어린잎을 세척 후 저장한 실험 결과와 유사하게 성장하 여 세척 시 손상된 부분에서 용출된 영양원을 미생물이 이용 하는 것으로 확인할 수 있었다. 따라서 적무 어린잎채소를 안 전하게 관리하기 위해서는 차아염소산나트륨 $150 \mathrm{mg} / \mathrm{L}$ 로 5 분간 세척 후 유통 및 소비 단계에서 $4^{\circ} \mathrm{C}$ 로 저온에서 유통 보관되어야 할 것으로 사료된다.

\section{감사의 글}

본 연구는 농촌진흥청 국립농업과학원 농업과학기술 연구 개발사업(과제번호: PJ01357802)의 지원에 의해 이루어진 것임.

\section{Conflict of interests}

The authors declare no potential conflict of interest.

\section{ORCID}

Song-Yi Choi https://orcid.org/0000-0002-5343-2945

Se-Ri Kim https://orcid.org/0000-0001-6857-8317

\section{References}

Brandl MT. Plant lesions promote the rapid multiplication of Escherichia coli O157:H7 on postharvest lettuce. Appl Environ Microbiol, 74, 5285-5289 (2008)

Callejon RM, Rodriguez-Naranjo MI, Ubeda C, HornedoOrtega R, Garcia-Parrilla MC, Troncoso AM. Reported foodborne outbreaks due to fresh produce in the United States and European Union: Trends and causes. Foodborne Pathog Dis, 12, 32-38 (2015)

Carstens CK, Salazar JK, Darkoh C. Multistate outbreaks of foodborne illness in the United States associated with fresh produce from 2010-2017. Front Microbiol, 10, 2667 (2019)

Choi MR, Lee SY. Inhibitory effects of chlorine dioxide and a commercial chlorine sanitizer against foodborne pathogens on lettuce. Korean J Food Cook Sci, 24, 445-451 (2008)

Elano RR, Kitagawa T, Bari ML, Kawasaki S, Kawamoto $\mathrm{S}$, Inatsu Y. Comparison of the effectiveness of acidified sodium chlorite and sodium hypochlorite in reducing Escherichia coli. Foodborne Pathog Dis, 7, 1481-1489 (2010)

Estrela C, Estrela CRA, Barbin EL, Spano JCE, Marchesan MA, Pecora JD. Mechanism of action of sodium hypochlorite. Braz Dent J, 13, 113-117 (2002)

Fukuzaki S. Mechanisms of actions of sodium hypochlorite in cleaning and disinfection processes. Biocontrol Sci, 11, 147-157 (2006)

Harapas D, Premier R, Tomkins B, Franz P, Ajlouni S. Persistence of Escherichia coli on injured vegetable plants. Int J Food Microbiol, 138, 232-237 (2010)

Hong SI, Lee ES, Kim MR, Kim DM. Microbiological safety of fresh-cut produce. Bulletin of Food Technology, 13, 3-35 (2000)

Huxsoll CC, Bolin H, King Jr. A Physicochemical Changes and Treatments for Lightly Processed Fruits and Vegetables. ACS Publications, Washington DC, USA, $p$ 203-215 (1989) 
Kim HJ, Shin J, Kim JE, Yang JY. Effect of gaseous chlorine dioxide on sterilization in industrial foodholding cabinets. J Food Hyg Saf, 34, 170-177 (2019a)

Kim JM. Use of chlorine dioxide as a biocide in the food industry. Food Industry and Nutrition, 6, 33-39 (2001)

Kim JG. Safety technology of fresh-cut fruit and vegetable. Food Preserv Process Ind, 4, 18-25 (2005)

Kim SH, Lee KI, Heo SY, Lee WJ. Research on fresh-cut fruits and vegetables. Korea Rural Economic Institute, $p$ 23-42 (2019b)

Kim SR, Chu HJ, Yi SW, Jang YJ, Sim WB, Hung NB, Kim WI, Kim HJ, Ryu KY. Investigation of hazardous microorganisms in baby leafy vegetables collected from a Korean market and distribution company. J Food Hyg Saf, 34, 526-533 (2019)

Kim WI, Jung HM, Kim SR, Park KH, Kim BS, Yun HJ, Yun JC, Ryu KY. Growth potential of Escherichia coli O157:H7 in lettuce leaf extract and on lettuce leaf surface. J Food Hyg Saf, 26, 296-301 (2011)

Kim YS, Park IS, Ha SD. Application sanitizer for the control of microorganisms in food. Food Science and Industry, 42, 26-51 (2009)

Kim YS, Park IS, Kim AY, Jeon KM, Seo YM, Choi SH, Lee YJ, Choi HC, Jeon DH, Kim HI, Ha SD. Application, utilization and management of ozone water in food manufacturing. J Food Hyg Saf, 23, 98-107 (2008)

MFDA. Additives Code. Ministry of Food and Drug Safety,
Cheongju, Korea (2020a)

MFDA. Food Code. Ministry of Food and Drug Safety, Cheongju, Korea (2020b)

Kown JY, Kim BS, Kim GH. Effect of washing methods and surface sterilization on quality of fresh-cut chicory (Clchorium intybus L.var. foliosum). Korean J Food Sci Technol, 38, 28-34 (2006)

Lee HH, Hong SI, Kim DM. Effect of postharvest treatments on storage quality of buckwheat sprouts. Korean J Food Sci Technol, 43, 98-104 (2011)

Ministry of Education. Model Guideline for Food Safety in School Food Service. 4th, Ministry of Education, Sejong, Korea, p 84-94 (2016)

Park SS, Sung JM, Jeong JW, Park KJ, Lim JH. Efficacy of electrolyzed water and aqueous chlorine dioxide for reducing pathogenic microorganism on Chinese cabbage. Korean J Food Sci Technol, 44, 240-246 (2012)

Van Haute S, Sampers I, Holvoet K, Uyttendaele M. Physicochemical quality and chemical safety of chlorine as a reconditioning agent and wash water disinfectant for fresh-cut lettuce washing. Appl Environ Microbiol, 79, 2850-2861 (2013)

Yun BH, Lee HS, An HM, Kim WI, Kim HY, Han SH, Kim HJ, Ryu JG, Kim SR. Effect of chlorine dioxide and sodium hypochlorite treatment on the reduction of foodborne pathogen in Korean chive. J Food Hyg Saf, 32, 154-162 (2017) 